\title{
Maintenance, Modifications, and Water Use in Private Gardens of Alt Empordà, Spain
}

\author{
Josep Padullés Cubino ${ }^{1,3}$, Josep Vila Subirós ${ }^{1}$, \\ and Carles Barriocanal Lozano ${ }^{1,2}$
}

Additional index words. Costa Brava, domestic gardens, irrigation, low-density urbanism, water management

Summary. Water scarcity in developed countries along the Mediterranean coast may be aggravated in the near future due to rising water demand. The recent growth of low-density urban developments in these regions has led to an increase in the number of private domestic gardens. These particular landscapes may account for a large proportion of total domestic water use. This article examines the features and management practices of private gardens in relation to their relative water requirements. To calculate this variable, we use a method based on the relative water needs of garden species and the area of vegetation cover. In addition, transformations in the layouts of the gardens over the last 5 years, as well as various expected changes, are assessed. In total, 258 domestic gardens along the coast of Catalonia were investigated and their owners interviewed. A list of all plants growing in the gardens was recorded. The results indicate that the presence of turf is related to professional landscaping design, property age, and swimming pool presence. Moreover, gardens with greater landscape water requirements have more efficient watering systems. We present a progressive strategy for garden restructuring that may reduce water use while increasing the number of orchards and fruit trees.

$\mathrm{W}$ ater stress across Europe may increase in the near future due to growing population numbers, lifestyle changes, and more frequent droughts (European Environment Agency, 2009). The associated growing water demand may affect water availability, especially in developed countries of the Mediterranean region (United Nations Environment Programme/ Mediterranean Action Plan-Plan Bleu, 2009). To ensure adequate water supply and to control demand for this resource, many international organizations, including the United Nations and European Union, have proposed the application of various comprehensive management plans (European Environment Agency, 2009; United Nations-Water, 2012). The effective implementation of such strategies

\footnotetext{
The authors would like to thank all of the participants who agreed to complete the survey.

Financial support was received from the Spanish Ministry of Economy and Competitiveness (CSO2010-17488; FPI BES-2011-046475).

${ }^{1}$ Department of Geography and Institute of the Environment, University of Girona, Pl. Ferrater i Mora, 1, 17071, Girona, Spain

${ }^{2}$ Department of Physical Geography and Regional Geographical Analysis, University of Barcelona, Montalegre, 6, 08001, Barcelona, Spain

${ }^{3}$ Corresponding author. E-mail: josep.padulles@udg. edu.
}

requires precise knowledge of the water management practices used in each territorial and socioeconomic context.

In the northwestern Mediterranean region, expanding urban areas significantly affect water demand (Domene and Saurí, 2006). Social preferences toward single-family houses, characteristic of Anglo-Saxon town planning, have led to an increase in domestic outdoor water consumption (Garcia et al., 2013; Saurí, 2003). This low-density urban model has been found to consume more water per capita than compact planning models (Askew and McGuirk, 2004; Parés-Franzi, 2005). Moreover, negative impacts across virtually all environmental parameters have been correlated with this form of residential development (Camagni et al., 2002; Cameron et al., 2012).

About half of all domestic water usage takes place in outdoor areas
(Domene and Saurí, 2006; Mayer et al., 1999; Salvador et al., 2011; Syme et al., 2004). Previous research reveals that garden irrigation represents a large portion of this consumption (Chesnutt and McSpadden, 1991; Renwick and Archibald, 1998). Several investigations have been conducted in recent years to understand the factors shaping garden management and design and the consequent impact on water consumption (Hurd et al., 2006; Larsen and Harlan, 2006; Mustafa et al., 2010; St. Hilaire et al., 2008; Yabiku, et al., 2008). Focusing on New Mexico, Hurd et al. (2006) demonstrated that the proportion of a garden occupied by turf is correlated with water price, the level of owner education, and the degree of owner awareness about the importance of water conservation. In the metropolitan area of Barcelona, Spain, Domene and Saurí (2003) found turf to be featured predominantly in the gardens of high-income neighborhoods. Larsen and Harlan (2006) also reported in a study carried out in Phoenix, AZ, that vegetation types found in front yards are related to income level. In the United States, preferences toward xeriscape gardens were found to be dependent on variables such as gender, the presence of children in the house, and owner knowledge of garden plants (Larson et al., 2009; St. Hilaire et al., 2010; Yabiku et al., 2008).

In Spain, despite major concerns about water consumption issues, few studies have explored this matter at length. Garcia et al. (2013) identified in the coastal area of Girona (Catalonia, northeastern Spain) four garden typologies (lawn, vegetable, ornamental and tree) and classified them according to their relative water needs and the socioeconomic profiles of the residents who owned them. Studying the Aljarafe region (Andalusia, southern Spain), FernándezCañero et al. (2011) concluded that private gardens are inefficiently

\begin{tabular}{llll}
\hline $\begin{array}{l}\text { Units } \\
\text { To convert U.S. to SI, } \\
\text { multiply by }\end{array}$ & U.S unit & SI unit & $\begin{array}{l}\text { To convert SI to U.S., } \\
\text { multiply by }\end{array}$ \\
\hline 0.3048 & $\mathrm{ft}$ & $\mathrm{m}$ & 3.2808 \\
0.0929 & $\mathrm{ft}^{2}$ & $\mathrm{~m}^{2}$ & 10.7639 \\
25.4 & inch(es) & $\mathrm{mm}$ & 0.0394 \\
1.6093 & mile $(\mathrm{s})$ & $\mathrm{km}$ & 0.6214 \\
2.5900 & mile & $\mathrm{km}^{2}$ & 0.3861 \\
$\left({ }^{\circ} \mathrm{F}-32\right) \div 1.8$ & ${ }^{\circ} \mathrm{F}$ & ${ }^{\circ} \mathrm{C}$ & $\left({ }^{\circ} \mathrm{C} \times 1.8\right)+32$
\end{tabular}


watered and mainly grown for aesthetic purposes without regard for environmental considerations. Furthermore, the authors reported that decisions to hire a professional maintenance service strongly depend on total garden area. A study in Zaragoza (Aragon, northeastern Spain) suggested that $60 \%$ of the surveyed gardens were overwatered (Salvador et al., 2011). However, in the metropolitan region of Barcelona, Domene and Saurí (2003) reported opposing data, where it was observed that garden irrigation generally did not meet plant watering requirements. These conflicting results suggest that more research is needed to understand the mechanisms determining water irrigation management habits and their connections to the structure and features of private urban landscapes.

Water requirements of private urban gardens may be calculated using several different factors, for which climate, plant composition, and the proportion of vegetated areas are the most relevant considerations. The Water Use Classifications of Landscape Species (WUCOLS) method proposed by Costello et al. (2000) allows one to calculate landscape water requirements based on a procedure that replaces the crop coefficient with a landscape coefficient. This method has been used effectively in several studies to assess water management practices in urban landscapes (Domene and Saurí, 2003; Endter-Wada et al., 2008; Nouri et al., 2013; Salvador et al., 2011).

In Catalonia, where the Alt Empordà is located, drought episodes in 2007 and 2008 spurred a prohibition against reallocating water suitable for human consumption to household outdoor uses such as watering gardens; this is outlined in Decree 84/2007 (Generalitat de Catalunya, 2007). Related water restrictions may become more commonplace in the context of global climate change (Llebot, 2010; Stocker et al., 2013). To effectively address this type of scenario in the future, precise knowledge of irrigation practices in private landscapes is needed to establish enhanced management measures adapted to each situation.

The aims of this paper were 1) to assess water management practices in domestic urban gardens in Alt Empordà, 2) to analyze landscape elements, structure, and irrigation systems in relation to relative landscape water requirements, 3 ) to explore the characteristics and motivations behind garden renovations carried out over the last 5 years to assess water-saving attitudes, and 4) to examine future changes in private landscape design and their consequent effects on water demand.

\section{Materials and methods}

STUdy AREA. The Alt Empordà is situated in northeastern Spain [lat. $42^{\circ} 14^{\prime} 53^{\prime \prime} \mathrm{N}$, long. $3^{\circ} 6^{\prime} 47^{\prime \prime} \mathrm{E}$ (Fig. 1)]. Low-density residential suburbs included in the study are distributed into five municipalities, occupying a total area of $128 \mathrm{~km}^{2}$. All of the suburban settlements are located around Aiguamolls de l'Empordà Natural Park $\left(47.31 \mathrm{~km}^{2}\right)$, an extremely valuable lowland coastal area (Saurí et al., 2000). The total population of the area is 45,219 inhabitants (Statistical Institute of Catalonia, 2013). The traditional agricultural landscape has changed drastically over the last 60 years with the expansion of urban areas from tourism. Within the last 30 years, the total number of houses has doubled, and $68 \%$ are now secondary residences only occupied for some portion of the year, particularly the summer months. Moreover, the number of residents has tripled and $\approx 38 \%$ are from other parts of Europe, especially France and Germany (Statistical Institute of Catalonia, 2013).

The climate is typically Mediterranean, with average annual temperatures of $\approx 15{ }^{\circ} \mathrm{C}$, oscillating from $30{ }^{\circ} \mathrm{C}$ in the summer to $3{ }^{\circ} \mathrm{C}$ in the winter. The average annual rainfall, mainly concentrated from autumn to spring, is $623 \mathrm{~mm}$. The entire area is located at an average height of $9.2 \mathrm{~m}$ above sea level.

Sample Selection. We studied residential areas within $1 \mathrm{~km}$ of the Natural Park of Aiguamolls de l'Empordà (International Union for Conservation of Nature category V). Using data from the cadastre (Directorate General for Cadastre Electronic Site, 2012) and ArcGIS 10 (Esri, Redlands, CA), a layer containing all detached, semiattached, and attached single-family houses was obtained. Following the method outlined by Lynch et al. (1974) and the ArcGIS 10 tool "subset features," we randomly selected a representative sample of 258 households from 6587 plots. When access to a selected house was not possible, the next house to the right on the same street was chosen. To include secondary residents in the survey and facilitate plant identification, all of the data were collected from May to July 2013.

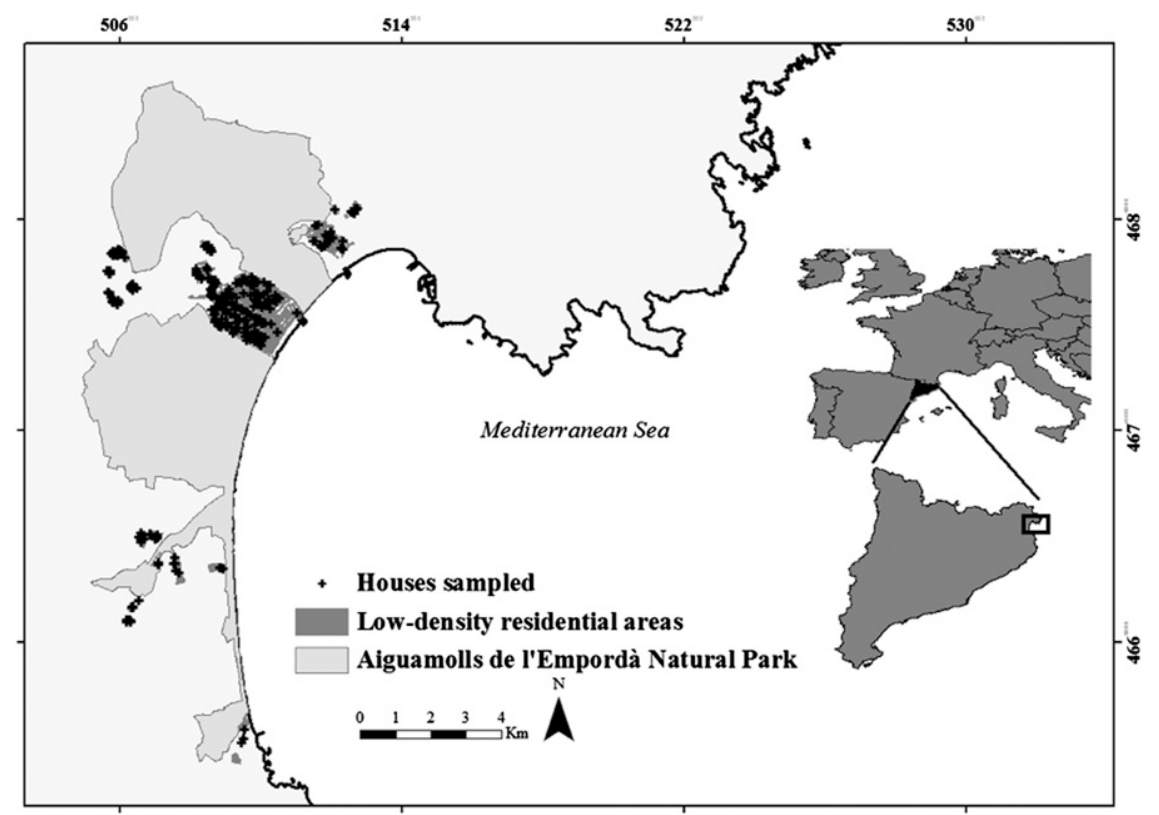

Fig. 1. The study area of Alt Empordà, Spain, showing the Aiguamolls de l'Empordà Natural Park, low-density residential areas, and sampled households; $1 \mathrm{~km}=0.6214$ mile. 
Data collection. All plants growing in the 258 private gardens were tabulated, including those in pots and ponds. For turf, a randomly selected plot of $0.5 \mathrm{~m}^{2}$ for each household was analyzed. For those plants that could not be identified at the species level, the genus was recorded. Each species was assigned to a single life form in accordance with the classification proposed by Raunkiaer (1934). Accordingly, plants were classified as phanerophytes (mostly trees and large shrubs), chamaephytes (mostly dwarf shrubs and some perennial herbs), hemicryptophytes (mainly biennial and perennial herbs, including those in which buds grow from a basal rosette), geophytes (mostly plants surviving as a bulb, rhizome, tuber, or root bud), and therophytes (including all annual plants). Native plants were classified following the methods of Bolós et al. (2005).

A team of the same two researchers visited all of the selected households. The first researcher recorded plant composition, while the second researcher conducted faceto-face surveys with each owner. The survey was designed to obtain information on the following: 1) characteristics of the property and the garden (e.g., age of the building, authorship of landscape design), 2) garden management practices, 3) irrigation scheduling and systems used, 4) changes in the garden structure over the last 5 years, and 5 ) expected changes to be made in the near future. The questionnaire contained dichotomous and multiplechoice questions.

Land cover data were also recorded during the survey. This category was classified into eight different subcategories: house, swimming pool, orchard, spontaneous vegetation, synthetic turf, turf, cultivated area (excluding turf; mainly trees, bushes, and flowers), and noncultivated area (excluding spontaneous vegetation; mainly paved areas). The presence of mulching, either organic or inorganic, was also recorded. Using ArcGIS 10, each land cover area was calculated from georeferenced orthoimages (Cartographic Institute of Catalonia, 2013).

CA L C U L A T ION OF NET IRRIGATION REQUIREMENTS. The WUCOLS method was proposed by Costello et al. (2000) and used to estimate net irrigation requirements
$\left(\mathrm{IR}_{n}\right)$. The technique is based on the application of a landscape coefficient $\left(K_{\mathrm{L}}\right)$ calculated from Eq. [1] as a function of the species factor $\left(k_{\mathrm{s}}\right)$, the density factor $\left(k_{\mathrm{d}}\right)$, and the microclimate factor $\left(k_{\mathrm{mc}}\right)$ that vary between and within different landscape vegetation types.

$$
K_{\mathrm{L}}=k_{\mathrm{s}} k_{\mathrm{d}} k_{\mathrm{mc}}
$$

The $k_{\mathrm{s}}$ parameter depends on the type of plant and the related water requirements. Based on expert evaluation, Costello and Jones (2014) tabulated these values for more than 3000 ornamental species in six areas of California. Species were classified in four main categories of water demands: very low [VL $\left.\left(k_{\mathrm{s}} \leq 0.10\right)\right]$, low $\left[\mathrm{L}\left(0.10<k_{\mathrm{s}} \leq 0.30\right)\right]$, moderate $\left[\mathrm{M}\left(0.40 \leq k_{\mathrm{s}} \leq 0.60\right)\right]$, and high $\left[\mathrm{H} \quad\left(0.70 \leq k_{\mathrm{s}} \leq 0.90\right)\right]$.

The $k_{\mathrm{s}}$ values of the first Californian areas were assigned to the plants inventoried in the gardens evaluated in this study. This region was chosen as the most climatically similar to our study site (Contreras et al., 2006). Species with VL water requirements were given a $k_{\mathrm{s}}$ of 0.1 , while average values were used for $\mathrm{L}(0.2), \mathrm{M}(0.5)$, and $\mathrm{H}(0.8)$ categories. Turf species were classified as cool season grasses $\left(k_{\mathrm{s}}=0.8\right)$ or warm season grasses $\left(k_{\mathrm{s}}=\right.$ 0.6) following Costello et al. (2000). Domesticated plants used for edible purposes were assigned to $\mathrm{H}$ water requirements. Moreover, all cacti not included in Costello and Jones (2014) were assigned to $\mathrm{L}$ water demands using a conservative approach. Both weeds and those species in pots or ponds were excluded from this part of the study as they do not meet the assumptions of standard conditions proposed by Costello et al. (2000). Only 50 plants $(7.9 \%)$ were discarded because they do not appear in the WUCOLS list.

For each type of vegetation cover (trees, shrubs and flowers, orchards, and turf), only one value of $k_{\mathrm{s}}$ was proposed. Continuing with a conservative approach, this was calculated as the maximum $k_{\mathrm{s}}$ value of all plants inventoried in each vegetation cover. Plots of spontaneous vegetation were excluded as they do not usually require any maintenance.

Densely planted gardens have a higher evapotranspiration than those less densely planted; therefore, a $k_{\mathrm{d}}$ factor is required to modify the species factor in these cases. In this work, a value of $k_{\mathrm{d}}=0.8$ was used for orchards and vegetation covers with one level of vegetation (trees or shrubs). If the landscape was represented by turf alone, or by two levels of vegetation (with trees and shrubs or flowers), a $k_{\mathrm{d}}$ of 1.0 was used. Those landscapes with three levels of vegetation featuring turf and trees, shrubs, and flowers were assigned a $k_{\mathrm{d}}$ of 1.2 .

Many gardens include a variety of microclimates, from cool, shaded areas protected from heat to very sunny areas or those exposed to the wind. This variability is incorporated through the $k_{\mathrm{mc}}$ factor. In this study, a value of 0.7 was assigned to all households as all landscapes were located in protected areas (Salvador et al., 2011).

Finally, net irrigation requirements $\left[\mathrm{IR}_{n}\right.$ (millimeters per square meter per day)] were calculated according to Eq. [2], as the sum of the products of the $K_{\mathrm{L}}$ of each vegetation cover and the reference evapotranspiration $\left[\mathrm{ET}_{0}\right.$ (millimeters per day)], and the area of each vegetation cover $\left[A_{\mathrm{v}}\right.$ (square meters) $]$. Note that $\mathrm{IR}_{n}$ is equivalent to landscape evapotranspiration.

$$
\mathrm{IR}_{n}=\sum_{i=1}^{n} K_{\mathrm{L} i} \mathrm{ET}_{0} A_{\mathrm{v} i}
$$

The resulting $\mathrm{IR}_{n}$ values were sorted again and gardens were classified into four groups (very low, low, moderate, and high). Each of the divisions was statistically split into quartiles.

Data analysis. For nominal variables, the chi-square test for homogeneity was used. Spearman's rank correlation coefficient was used to analyze correlations between continuous numerical variables. For numerical variables, the Kruskal-Wallis analysis of variance test was used to compare garden groups. When the result was significant, post hoc paired comparisons were performed following the methods of Dunn (1964). All analyses were conducted using SPSS (version 19 for Windows; IBM Corp., Armonk, NY). Significance was determined at $P \leq$ 0.05 . 


\section{Results and discussion}

GARDEN FEATUREs. Garden area influences many of the decisions made by homeowners in terms of both garden design and maintenance. In this study, garden size varied between 37 and $2273 \mathrm{~m}^{2}$, with a mean value of $283 \mathrm{~m}^{2}$. This last number is comparatively lower than those reported in many other garden studies (Bernholt et al., 2009; Bigirimana et al., 2012; Marco et al., 2008), all of which were over $600 \mathrm{~m}^{2}$. However, this value is higher than that reported by Gaston et al. (2005), for which a mean value of $151 \mathrm{~m}^{2}$ was reported for private gardens of Sheffield (United Kingdom). Fifty-one percent of garden area consisted of paved areas and other artificial surfaces, while $49 \%$ consisted of vegetation. The average area occupied by trees, shrubs, and flowers was $80 \mathrm{~m}^{2}(28 \%)$, while turf occupied $54 \mathrm{~m}^{2}(19 \%)$ and orchards took up $4 \mathrm{~m}^{2}$ (1\%). Table $\mathrm{l}$ shows garden cover area according to the four $\mathrm{IR}_{n}$ garden groups. The amount of surface occupied by spontaneous vegetation, orchard, and synthetic turf, as well as the proportion of households with mulching elements, were not found to vary significantly among groups. Surface area occupied by trees, bushes and flowers, turf, pavement, and other artificial surfaces significantly increased as $\mathrm{IR}_{n}$ increased.

Associations among different vegetation covers, housing characteristics, and management practices are included in Table 2. Turf was only present in $46 \%$ of the cases. According to St. Hilaire et al. (2008), in areas such as the Mediterranean region, where water is scarce or expensive, turf ratios tend to be low.

The presence of turf was also found to be positively correlated with property age $\left(\chi^{2}=14.42, \mathrm{df}=3, P \leq\right.$ $0.01)$. Older buildings, possessing gardens up to 51 years old, as well as newly built gardens of barely 2 years, were found in the sampled houses. This correlation may suggest that new building owners opt for more xeriscape landscaping to reduce water consumption. Moreover, gardens with turf were also associated with professional landscaping design $\left(\chi^{2}=\right.$ $5.77, \mathrm{df}=1, P \leq 0.05)$. This finding implies that households that can afford the cost of turf maintenance can also hire a professional landscaper to design the garden. In this sense, it is worth highlighting that professional landscapers might promote turf species adapted to the particular climate in which a garden is being designed. The positive relationship between turf and pool presence was also confirmed $\left(\chi^{2}=3.55, \mathrm{df}=1, P \leq 0.05\right)$.

Gardens with trees, shrubs, and flowers were positively associated with building age $\left(\chi^{2}=18.14, \mathrm{df}=\right.$ $3, P \leq 0.01)$ and secondary residences $\left(\chi^{2}=4.06, \mathrm{df}=1, P \leq 0.05\right)$. In contrast, the presence of orchards is highly dependent on whether a garden is located at a primary residences $\left(\chi^{2}=8.40, \mathrm{df}=3, P \leq 0.01\right)$ and whether there is a swimming pool in the yard $\left(\chi^{2}=4.37, \mathrm{df}=1, P \leq 0.05\right)$.
These results suggest that the gardens of households inhabited yearround hold productive purposes, while the gardens of secondary residences are mostly ornamental. In other studies, garden plants in lowincome neighborhoods have been found to have a utilitarian function, while in high-standing neighborhoods, they mainly have an ornamental function (Bigirimana et al., 2012; Douglas and Lawrence, 2011).

Vegetal biodiversity. A total of 635 genera and species were identified in all of the sampled gardens, the most abundant of which were rose [Rosa sp. $(58.3 \%)$ ], olive [Olea europaea $(45.6 \%)]$, japanese spindle [Euonymus japonicus (44.0\%)], lemon [Citrus limon (43.2\%)], and canary island date palm [Phoenix canariensis (42.1\%)] (Table 3). Recent studies assessing garden plant biodiversity have reported considerably different numbers of species: 1116 in Sheffield, England (Smith et al., 2006); 973 in Lauris, France (Marco et al., 2008); 567 in Bujumbura, Burundi (Bigirimana et al., 2012); 235 in Bangalore, India (Jaganmohan et al., 2012); and 116 in Niamey, Niger (Bernholt et al., 2009 ). Although the proportion of exotic plants is usually higher than that of native plants, these percentages vary considerably between gardens (see Bigirimana et al., 2012). In our study, $68 \%$ of all plants were exotic.

Of all plants studied, $81 \%$ correspond to ornamental species, $15 \%$ to weeds, $9 \%$ to edible plants, and $2 \%$ to plants with other uses (note that the

Table 1. Garden features for each category of garden according to net irrigation requirements $\left(\mathrm{IR}_{n}\right)$ found in Alt Empordà, Spain.

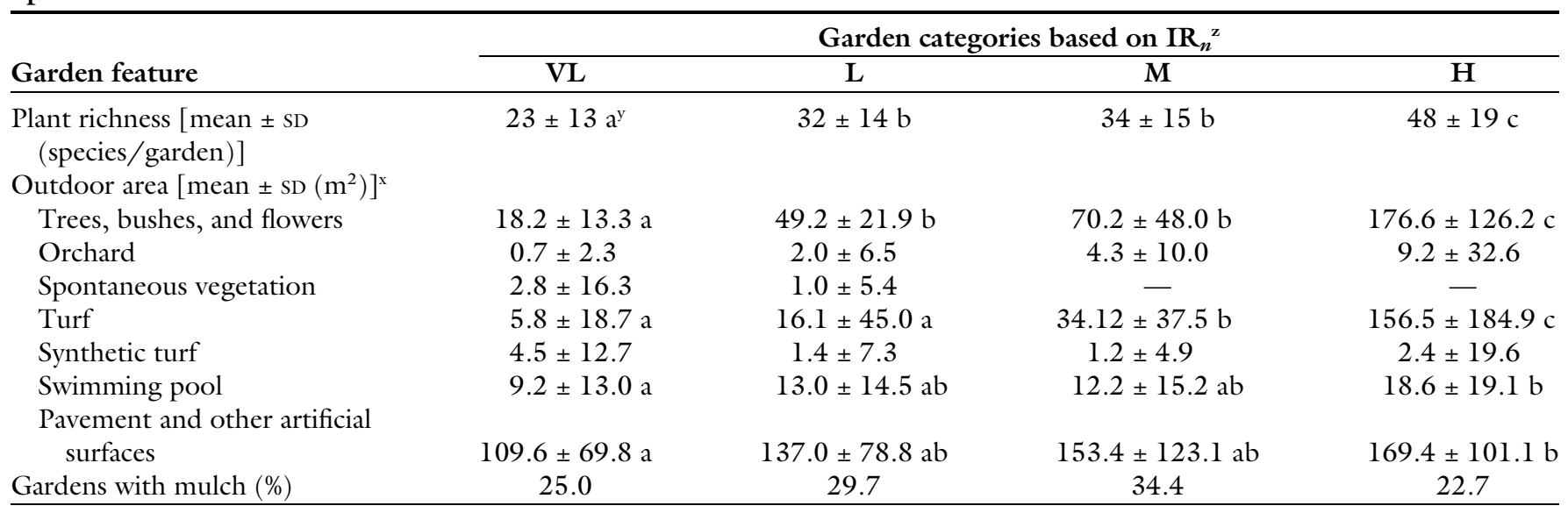

${ }^{z}$ Classification of gardens based on $\mathrm{IR}_{n}$ as very low $(\mathrm{VL})$, low $(\mathrm{L})$, moderate $(\mathrm{M})$, and high $(\mathrm{H})$.

yAny two means within a row not followed by the same letter are significantly different by Dunn's test at $P \leq 0.05$

${ }^{x} 1 \mathrm{~m}^{2}=10.7639 \mathrm{ft}^{2}$ 
Table 2. Housing characteristics and garden management practices for several vegetation covers in Alt Empordà, Spain ${ }^{\mathrm{z}}$.

\begin{tabular}{|c|c|c|c|c|c|c|c|c|c|c|}
\hline \multirow[b]{2}{*}{ Vegetation cover } & \multicolumn{2}{|c|}{$\begin{array}{l}\text { Automatic } \\
\text { sprinkling }^{\mathrm{y}}\end{array}$} & \multicolumn{2}{|c|}{ Type of residence ${ }^{y}$} & \multicolumn{2}{|c|}{ Landscaper design $^{y}$} & \multicolumn{2}{|c|}{ Swimming pooly } & \multicolumn{2}{|c|}{ Building age $^{\mathrm{x}}$} \\
\hline & $\chi^{2}$ & $r_{\phi}$ & $\chi^{2}$ & $r_{\phi}$ & $\chi^{2}$ & $r_{\phi}$ & $\chi^{2}$ & $r_{\phi}$ & $\chi^{2}$ & $r_{\phi}$ \\
\hline Trees, bushes, and flowers & 0.30 & 0.03 & $4.06^{*}$ & 0.13 & 0.33 & 0.04 & 1.30 & 0.07 & $18,14 * *$ & 0.27 \\
\hline Turf & $35.6^{* *}$ & 0.37 & 1.91 & -0.09 & $5.77^{*}$ & 0.15 & $3.55^{*}$ & 0.12 & 14.42 ** & 0.24 \\
\hline Orchard & 0.0 & -0.04 & 8.40 ** & -0.18 & 2.86 & -0.11 & $4.37^{*}$ & -0.13 & 1.52 & 0.08 \\
\hline Spontaneous vegetation & 0.99 & -0.06 & 3.50 & -0.12 & 0.04 & 0.01 & 0.12 & -0.02 & 4.16 & 0.13 \\
\hline
\end{tabular}

${ }^{2}$ For each association Pearson's chi-square $\left(\chi^{2}\right)$ and Phi $\left(r_{0}\right)$ values are presented.

"Chi-square test based on dichotomous responses $(\mathrm{df}=\mathrm{l})$ : “use of automatic sprinkling" $(0=$ no, $1=$ yes $)$, "kind of residence" $(0=$ secondary residences, $1=$ primary residences), "professional landscaper design" $(0=$ no; $1=$ yes $)$, and presence of swimming pool $(0=$ no, $1=$ yes $)$.

${ }^{x}$ Chi-square test based on four types of responses $(\mathrm{df}=3)$ : building age (less than 5 years old $/ 5-20$ years old $/ 20-51$ years old $/ \mathrm{more} 5 \mathrm{l}$ than years old).

*, ** Significant at $P \leq 0.05$ or 0.01 , respectively.

sum of percentages may differ from $100 \%$ as some of the same species can be used for multiple purposes). These data suggest that the gardens in the study area are mainly grown for aesthetic reasons.

The mean number of species per garden was 34.0 , although there may be significant differences between groups (Kruskal-Wallis $\mathrm{H}=56.1$, $\mathrm{df}=$ 3, $P \leq 0.01)$. A positive correlation exists between plant richness and $\mathrm{IR}_{n}$ (Spearman's $\mathrm{R}^{2}=0.528, P \leq 0.01$ ). Previous research has shown plant richness to be influenced by socioeconomic and cultural factors (e.g., Hope et al., 2003; Martin et al., 2003). Determining the best predictors of plant richness for each unique situation may be a key factor in guiding water management policies.

The most abundant life forms found were phanerophytes (40.6\%) and chamaephytes $(21.9 \%)$. This indicates that the private landscapes in our study area mainly consist of mature plant communities. Comparatively, these consolidated gardens may require less irrigation than younger gardens. In contrast to reports by Smith et al. (2005) in Sheffield, England, the number of plants in these two categories was found to be correlated with house age (Spearman's $\left.\mathrm{R}^{2}=0.28, P \leq 0.01\right)$. Therefore, water managers should focus on assessing water use in young and newly built gardens composed of unconsolidated plant communities and less established plants.

Turfgrass species offer the significant ecological function of reducing erosion and allowing for more efficient rainwater use. However, if inadequately maintained or if occupying oversized areas, these species can also waste a significant amount of water (Wade et al., 2007). The most common turfgrass plant recorded in the sampled gardens was tall fescue [Festuca arundinacea (26.6\%)], which is unlikely to be the species most suited to the summer conditions of the study area. Though this cold-season plant maintains a healthy appearance in the winter, it requires large amounts of water in summer in return for minimal ornamental value. In smaller proportions, we also identified perennial ryegrass (Lolium perenne), bermudagrass (Cynodon dactylon), kentucky bluegrass (Poa pratensis), bentgrass (Agrostis sp.), and st. augustinegrass (Stenotaphrum secundatum). In this sense, more appropriate droughttolerant and noninvasive species, such as zoysiagrass (Zoysia japonica), should be promoted.

LANDSCAPE MANAGEMENT AND DESIGN. Owners were asked about the design and maintenance requirements of their gardens (Table 4). Many of the water needs and functional characteristics of a garden depend on the initial garden design. A well-planned garden should take into account a set of parameters such as hydrozone plant groupings and the local climate, topography, and native vegetation (Wade et al., 2007). Although almost $52 \%$ of owners were involved in the design of their gardens, professional landscaper intervention was especially important in $25.2 \%$ of all cases. This contrasts the results of Fernández-Cañero et al. (2011) in Aljarafe, Spain, which showed a higher proportion $(86.3 \%)$ of owners involved in the design of their gardens.

With respect to management practices, household members performed the maintenance of their gardens in $80.3 \%$ of all cases. Similar values were obtained in Georgia (United States), where three of every four owners were engaged in landscape maintenance (Varlamoff et al., 2001), and in Aljarafe, Spain, where $83 \%$ of the owners performed upkeep (Fernández-Cañero et al., 2011). Professional gardening companies were employed for garden pruning and mowing in $11.2 \%$ of the cases. This percentage is considerably lower than the $16 \%$ to $43 \%$ reported in surveys from Ohio, NC, and Oregon in the United States (Nielson and Smith, 2005; Osmond and Hardy, 2004; Robbins et al., 2001). It is therefore important to promote environmental and xeriscape education for homeowners through water conservation campaigns.

Garden IRrigation. One of the most important factors for predicting actual water use is the type of irrigation system (Endter-Wada et al., 2008). As shown in Table 5, roughly half of the respondents use a hose to water all parts of the garden. A watering can is only used by $28.7 \%$ of the respondents, mostly for watering potted plants. In contrast, drip irrigation, which has $75 \%$ to $90 \%$ efficiency (Fuentes, 2003), is used in less than $10 \%$ of all cases. Overall efficiency is lacking, with $77.7 \%$ of gardens not equipped with automated irrigation. This percentage is higher than the $43 \%$ reported in gardens of Aljarafe, Spain (Fernández-Cañero et al., 2011 ), and the $69.1 \%$ presented in a study developed by the America Water Works Association Research Foundation (Mayer et al., 1999) that surveyed regions across the United States. Although automated systems are often programmed to dispense large amounts of water regardless of season and the needs of plants (Martin, 2001), the use of these systems nevertheless allows for greater control, efficiency, and adjustments to the amount of water applied. These features reduce the cost of general maintenance while also saving water 
Table 3. The $\mathbf{5 0}$ most abundant species and their relative frequencies in sampled gardens in Alt Empordà, Spain. For each plant, the table shows relative frequency, family, life form (LF), uses, native, and water requirement according to the species factor $\left(k_{s}\right)$.

\begin{tabular}{|c|c|c|c|c|c|c|c|}
\hline Common name & Scientific name & Relative frequency (\%) & Family & $\mathbf{L F}^{\mathrm{z}}$ & $\mathrm{Use}^{\mathrm{y}}$ & Native & $k_{\mathrm{s}}^{\mathrm{x}}$ \\
\hline Rose & Rosa sp. & 58.3 & Rosaceae & $\mathrm{Ph}$ & Or & No & M \\
\hline Olive & Olea europaea & 45.6 & Oleaceae & $\mathrm{Ph}$ & Or & Yes & VL \\
\hline Lemon & Citrus limon & 43.2 & Rutaceae & $\mathrm{Ph}$ & Or, Ed & No & M \\
\hline Canary island date palm & Phoenix canariensis & 42.1 & Arecaceae & $\mathrm{Ph}$ & Or & No & $\mathrm{L}$ \\
\hline Rosemary & Rosmarinus officinalis & 41.3 & Lamiaceae & $\mathrm{Ch}$ & Or & Yes & $\mathrm{L}$ \\
\hline Garden geranium & Pelargonium zonale & 38.6 & Geraniaceae & $\mathrm{Ch}$ & Or & No & M \\
\hline Sago palm & Cycas revoluta & 38.2 & Cycadaceae & $\mathrm{Ph}$ & Or & No & M \\
\hline African daisy & Osteospermum sp. & 37.8 & Asteraceae & $\mathrm{Ch}$ & Or & No & $\mathrm{L}$ \\
\hline English ivy & Hedera belix & 36.7 & Araliaceae & $\mathrm{Ph}$ & Or, We & Yes & M \\
\hline Oleander & Nerium oleander & 35.9 & Apocynaceae & $\mathrm{Ph}$ & Or & Yes & $\mathrm{L}$ \\
\hline Annual bluegrass & Poa annua & 34.4 & Poaceae & Th & $\mathrm{We}$ & Yes & - \\
\hline Mock orange & Pittosporum tobira & 30.1 & Pittosporaceae & $\mathrm{Ph}$ & Or & No & $\mathrm{L}$ \\
\hline Orange & Citrus sinensis & 28.2 & Rutaceae & $\mathrm{Ph}$ & Or, Ed & No & M \\
\hline Lavender & Lavandula angustifolia & 28.2 & Lamiaceae & $\mathrm{Ch}$ & Or & Yes & $\mathrm{L}$ \\
\hline Yellow wood sorrel & Oxalis corniculata & 27.8 & Oxalidaceae & Th & We & Yes & - \\
\hline Italian cypress & Cupressus sempervirens & 27.4 & Cupressaceae & $\mathrm{Ph}$ & Or & No & $\mathrm{L}$ \\
\hline Palmer's sedum & Sedum palmeri & 27.0 & Crassulaceae & $\mathrm{Ch}$ & Or & No & $\mathrm{L}$ \\
\hline Tall fescue & Festuca arundinacea & 26.6 & Poaceae & $\mathrm{H}$ & Or & Yes & CS \\
\hline Crimson bottlebrush & Callistemon citrinus & 25.5 & Myrtaceae & $\mathrm{Ph}$ & Or & No & $\mathrm{L}$ \\
\hline Asparagus fern & Asparagus densiflorus & 24.7 & Asparagaceae & $\mathrm{Ch}$ & Or & No & M \\
\hline Sweet bay & Laurus nobilis & 24.7 & Lauraceae & $\mathrm{Ph}$ & Or & Yes & $\mathrm{L}$ \\
\hline Hens and chickens & Echeveria sp. & 23.9 & Crassulaceae & $\mathrm{Ch}$ & Or & No & $\mathrm{L}$ \\
\hline Mediterranean fan palm & Chamaerops humilis & 20.1 & Arecaceae & $\mathrm{Ph}$ & Or & Yes & $\mathrm{L}$ \\
\hline Calla lily & Zantedeschia aethiopica & 20.1 & Araceae & $\mathrm{G}$ & Or & No & M \\
\hline Canna & Canna $\times$ generalis & 19.7 & Cannaceae & $\mathrm{H}$ & Or & No & M \\
\hline Spider plant & Chlorophytum comosum & 19.7 & Asparagaceae & $\mathrm{H}$ & Or & No & $\mathrm{L}$ \\
\hline Pink/carnation & Dianthus sp. & 19.7 & Caryophyllaceae & $\mathrm{Ch}$ & Or & No & M \\
\hline Euryops & Euryops pectinatus & 19.7 & Asteraceae & $\mathrm{Ph}$ & Or & No & $\mathrm{L}$ \\
\hline Horseweed & Conyza sp. & 19.3 & Asteraceae & Th & We & No & - \\
\hline Strawberry & Fragaria vesca & 18.9 & Rosaceae & $\mathrm{Ch}$ & $\mathrm{Ed}$ & Yes & M \\
\hline Iris & Iris sp. & 18.9 & Iridaceae & G & Or & No & M \\
\hline Lantana & Lantana camara & 18.9 & Verbenaceae & $\mathrm{Ph}$ & Or & No & $\mathrm{L}$ \\
\hline American arborvitae & Thuja occidentalis & 18.9 & Cupressaceae & $\mathrm{Ph}$ & Or & No & M \\
\hline Aloe & Aloe maculata & 18.5 & Xanthorrhoeaceae & $\mathrm{Ph}$ & Or & No & $\mathrm{L}$ \\
\hline Canary island rose & Aeonium arboreum & 18.1 & Crassulaceae & $\mathrm{Ch}$ & Or & No & $\mathrm{L}$ \\
\hline Chilean jasmine & Mandevilla laxa & 18.1 & Apocynaceae & $\mathrm{Ph}$ & Or & No & M \\
\hline
\end{tabular}

${ }^{2} \mathrm{Life}$ form (LF): phanerophytes [ $\mathrm{Ph}$ (mostly trees and large shrubs)], chamaephytes [Ch (mostly dwarf shrubs and some perennial herbs)], therophytes [Th (including all annual plants)], geophytes [G (plants surviving as a bulb, rhizome, tuber, or root bud)], and hemicryptophytes [H (mainly biennial and perennial herbs)].

'Plant uses: ornamental (Or), edible (Ed), medicinal (Me), and weed (We).

${ }^{x}$ Species factor $\left(k_{\mathrm{s}}\right)$ : weeds/no data $(-)$, very low $(\mathrm{VL})$, low $(\mathrm{L})$, moderate $(\mathrm{M})$, and high $(\mathrm{H})$, cold-season turf species $(\mathrm{CS})$.

(Fernández-Cañero et al., 2011; Martín et al., 2004).

As was expected, the presence of turf was found to be positively associated with the use of automatic sprinkler irrigation $\left(\chi^{2}=35.56, \mathrm{df}=\right.$ $1, P \leq 0.01)$. Although only $16 \%$ of respondents use this method, most apply it without taking the different hydrozones into account.

We classified households by irrigation system into the four $\mathrm{IR}_{n}$ 
Table 4. Percentage of gardens reported by owners in relation to their landscape management and design in Alt Empordà, Spain.

\begin{tabular}{|c|c|c|c|c|c|c|c|}
\hline & $\mathrm{NR}^{\mathrm{z}}$ & Nobody & Myself & Relatives & $\begin{array}{c}\text { Landscape } \\
\text { professional }\end{array}$ & $\begin{array}{c}\text { Together with } \\
\text { relatives }\end{array}$ & Other situations \\
\hline Question & \multicolumn{7}{|c|}{ Responses (\%) } \\
\hline Who designed the garden? & 1.6 & - & 37.6 & 18.6 & 25.19 & 14.3 & 2.7 \\
\hline Who selected the plants? & 2.3 & 0.4 & 51.2 & 22.5 & 3.10 & 16.3 & 4.3 \\
\hline Who prunes and mows the garden? & 3.1 & 0.4 & 48.1 & 18.2 & 11.24 & 14.0 & 5.0 \\
\hline Who waters the garden? & 2.7 & 一 & 60.1 & 16.7 & 3.49 & 15.1 & 1.9 \\
\hline
\end{tabular}

${ }^{2}$ No response.

Table 5. Percentage of sampled gardens using distinct irrigation systems for each part of the garden in Alt Empordà, Spain.

\begin{tabular}{|c|c|c|c|c|c|c|c|c|}
\hline \multirow[b]{3}{*}{ Irrigation system } & \multicolumn{8}{|c|}{ Garden features } \\
\hline & Do not use & All & Turf & Trees & Bushes & Flowers and pots & Orchard & Other \\
\hline & \multicolumn{8}{|c|}{ Responses (\%) } \\
\hline Hand watering with watering can & 71.3 & 14.3 & 1.2 & - & 0.4 & 11.6 & 0.8 & 0.4 \\
\hline Sprinkling/manual activation & 91.1 & 5.8 & 1.9 & - & 0.4 & 0.8 & - & - \\
\hline Sprinkling/automatic activation & 83.7 & 10.9 & 5.0 & - & - & 0.4 & - & - \\
\hline
\end{tabular}

Table 6. Percentage of gardens using distinct watering systems and classified according to net irrigation requirements $\left(\mathrm{IR}_{n}\right)$ in Alt Empordà, Spain.

\begin{tabular}{|c|c|c|c|c|}
\hline \multirow[b]{3}{*}{ Irrigation system } & \multicolumn{4}{|c|}{ Garden categories based on $\mathrm{IR}_{n}{ }^{\mathrm{z}}$} \\
\hline & $\mathrm{VL}$ & $\mathrm{L}$ & $\mathbf{M}$ & $\mathbf{H}$ \\
\hline & \multicolumn{4}{|c|}{ Responses (\%) } \\
\hline Hand watering with watering can & 27.5 & 23.8 & 22.5 & 18.8 \\
\hline Sprinkling/manual activation & 6.3 & 8.8 & 6.3 & 7.5 \\
\hline Sprinkling/automatic activation & 2.5 & 5.0 & 13.8 & 31.3 \\
\hline
\end{tabular}

${ }^{2}$ Classification of gardens based on $\mathrm{IR}_{n}$ as very low $(\mathrm{VL})$, low $(\mathrm{L})$, moderate $(\mathrm{M})$, and high $(\mathrm{H})$.

garden groups. As illustrated in Table 6 , the number of households using drip or sprinkler irrigation systems increases as $\mathrm{IR}_{n}$ increases $\left(\chi^{2}=\right.$ 29.00, df $=3, P \leq 0.01)$. Thus, in gardens with higher $\mathrm{IR}_{n}$, the presence of automatic sprinkler irrigation (31.3\% of all cases) and drip irrigation that is either manual (10.0\%) or automatic $(8.8 \%)$ is especially significant. Accordingly, in distinct studies developed in Australia (Syme et al., 2004), Spain (Domene et al., 2005), and the United States (Chesnutt and McSpadden, 1991), it was shown that households with more sophisticated and efficient watering systems also possess more water-intensive gardens than those using traditional irrigation techniques. In contrast, households with very low $\mathrm{IR}_{n}$ rely primarily on hose $(56.3 \%)$ and watering can $(27.5 \%)$ use.
With respect to watering frequency, Table 7 shows that more than half of the gardens $(57.4 \%)$ were not watered during the winter, while $36.4 \%$ were watered every day during the summer. These results contrast those of Fernández-Cañero et al. (2011), who reported that almost half of the gardens in that study $(48.8 \%)$ were watered daily in summer, with a large majority (70\%) not being watered in winter. Larson et al. (2009) suggested that frequent summer irrigation was associated with garden maintenance for neighborhood appearance, while winter irrigation was related to biocentric (environmentally oriented) worldviews. Surprisingly, only $1.2 \%$ of the respondents claimed to water the garden only when necessary. This result is likely due to a lack of knowledge concerning plant garden maintenance.
Garden owners were asked what time of day they usually water their garden (Table 8 ). About half of the respondents water the garden in the evening or at night. However, only $21.7 \%$ of the owners modulate irrigation depending on the season, and $5.0 \%$ are indifferent to these issues. These trends could be improved by promoting more sustainable garden management practices.

GARDEN Transformation. The questionnaire asked owners about changes made to the layouts of their gardens over last 5 years and the motivations for these changes (Table 9). At least three quarters of the respondents have made some meaningful changes during this period. Similarly, in a study in Phoenix, AZ, Larsen and Harlan (2006) reported that $70 \%$ of respondents made changes in their landscapes. The most 
Table 7. Percentage of gardens based on the frequency of watering in each season in Alt Empordà, Spain.

\begin{tabular}{lccccccc}
\hline & $\mathbf{N R}^{\mathbf{z}}$ & Every day & Alternate days & Every $\mathbf{3 ~ d}$ & Every week & Do not water & When necessary \\
\cline { 2 - 8 } Season & \multicolumn{7}{c}{ Responses (\%) } \\
\hline Winter & 8.9 & 1.6 & 2.3 & 3.9 & 14.0 & 57.4 & 12.0 \\
Summer & 3.5 & 36.4 & 24.0 & 18.2 & 14.0 & 2.7 & 1.2 \\
\hline
\end{tabular}

${ }^{2}$ No response.

Table 8. Percentage of gardens based on the time of day of watering in Alt Empordà, Spain.

\begin{tabular}{lcccccccr}
\hline \multicolumn{7}{c}{ Time of day to water the garden (\%) } \\
\hline $\mathbf{N R}^{\mathbf{z}}$ & Morning & Noon & Afternoon & Evening & Night & Morning and night & Depending on the season & Indifferent \\
\hline 4.1 & 6.6 & 0.4 & 11.2 & 40.7 & 5.9 & 4.3 & 21.7 & 5.0 \\
\hline${ }^{2}$ No response.
\end{tabular}

Table 9. Total number of expected and realized changes (2008-13) in private landscapes and the proportion of total changes based on distinct circumstances in Alt Empordà, Spain.

\begin{tabular}{|c|c|c|c|c|c|c|c|c|}
\hline \multirow[b]{2}{*}{ Change } & \multicolumn{2}{|c|}{$\begin{array}{c}\text { Total changes } \\
\text { (no.) }\end{array}$} & \multicolumn{6}{|c|}{ Reasons for realized changes (\%) } \\
\hline & Expected & $\begin{array}{c}\text { Realized } \\
2008-13^{z}\end{array}$ & $\begin{array}{l}\text { Saving } \\
\text { water }\end{array}$ & $\begin{array}{l}\text { Saving } \\
\text { money }\end{array}$ & $\begin{array}{l}\text { Saving } \\
\text { time }\end{array}$ & $\begin{array}{c}\text { To make my } \\
\text { garden beautiful }\end{array}$ & $\begin{array}{l}\text { To improve the } \\
\text { recreational space }\end{array}$ & Other \\
\hline Pavement of part of the garden & 10 & 23 & 3.7 & 7.4 & 22.2 & 18.5 & 40.7 & 7.4 \\
\hline Make an orchard & 7 & 9 & - & - & - & 30.0 & 10.0 & 60.0 \\
\hline Remove turf & 1 & 32 & 25.0 & 2.27 & 22.7 & 22.7 & 18.2 & 9.1 \\
\hline Remove plants & - & 15 & 16.7 & 11.1 & 27.8 & 16.7 & 22.2 & 5.6 \\
\hline Add or change plants & 18 & 27 & - & 3.03 & 18.2 & 57.6 & 21.2 & - \\
\hline Remove trees & 2 & 26 & - & - & 3.7 & 40.7 & 51.9 & 3.7 \\
\hline Plant of fruit trees & 4 & 23 & 10.3 & 10.3 & 10.3 & 48.3 & 17.2 & 3.5 \\
\hline Change the watering system & 4 & 6 & 36.4 & 18.2 & 36.4 & 9.09 & - & - \\
\hline Install mulching elements & - & 6 & - & - & - & 12.5 & 62.5 & 25.0 \\
\hline
\end{tabular}

${ }^{2}$ Each garden may have more than one reason to apply changes.

common modification reported in these studies was the addition of vegetation. In contrast, our study indicated that the most frequent modification was turf removal, performed in $12.4 \%$ of the households. The main reasons for this movement were to save water $(25.0 \%)$, to save time $(22.7 \%)$, and for garden beautification $(22.7 \%)$. Less prevalent transformations executed for water-saving purposes included the installation of synthetic turf and irrigation system replacement. Other common changes included plant replacement, tree removal, fruit tree planting, and paving parts of the garden. The main modifications planned in the near future as reported by the owners were plant incorporation (18 cases), paving part of the garden (10 cases), and orchard construction (7 cases).

Although there is no direct relationship between the drought episodes of 2007 and 2008 and such garden transformations, a general trend toward saving water is evident during this period. According to planned changes reported by the owners, this phenomenon seems likely to persist in the near future. As such, garden transformations that are implemented not strictly for saving water, such as paving, installing synthetic turf, or upgrading the watering system, may play an indirect but important role in reducing water demand. These findings suggest that gardens are slowly being adapted to the current climatic and socioeconomic conditions. This may prove highly important when future drought episodes once again activate restrictions on garden water use.

\section{Conclusions}

The main goal of this study was to assess water management practices in private urban gardens of Alt
Empordà, Spain. More than half of the outdoor spaces studied were found to be composed of pavement or other artificial surfaces. However, the vegetated surfaces may consume a large proportion of domestic water. Thus, detecting inefficiencies in garden water use is essential for guiding policies and water management measures and for adapting to climate change.

One of the most compelling results of this research is the significant correlation found between turf use and property age, swimming pool presence, and most importantly, automatic sprinkler irrigation use. Although $77 \%$ of the gardens do not use an automatic irrigation system, results show that more efficient watering systems are used as landscape irrigation requirements increase.

The high proportion of ornamental plant species discovered in this 
study indicates that the sampled gardens are mainly cultivated for aesthetic purposes. However, an increase in the number of orchards has been detected over the last 5 years, likely in response to the economic crisis developing in the country since 2008. This fact appears to complement the growing number of fruit trees reported in the same period. These observations may embody a general trend toward changes in the functions of household gardens, which could increase water consumption to enhance household food security.

Garden maintenance, design, and associated activities are mainly performed by the homeowner together with other household members. It is therefore important to promote environmental education through water conservation campaigns.

In absolute terms, there has not been a significant number of changes made to the structure of gardens over the last 5 years. However, it should be emphasized that the most frequently applied modification was turf removal, performed mainly for water conservation. The assimilation of data from continuing studies on home garden modification may reveal a general trend toward reducing water consumption.

\section{Literature cited}

Askew, L.E. and P.M. McGuirk. 2004. Watering the suburbs: Distinction, conformity and the suburban garden. Austral. Geogr. 35:17-37.

Bernholt, H., K. Kehlenbeck, J. Gebauer, and A. Buerkert. 2009. Plant species richness and diversity in urban and periurban gardens of Niamey, Niger. Agrofor. Syst. 77:159-179.

Bigirimana, J., J. Bogaert, C. De Cannière, M.-J. Bigendako, and I. Parmentier. 2012. Domestic garden plant diversity in Bujumbura, Burundi: Role of the socioeconomical status of the neighborhood and alien species invasion risk. Landsc. Urban Plan. 107:118-126.

Bolós, O., J. Vigo, R.M. Masallers, and J.M. Ninot. 2005. Flora manual dels Països Catalans. 3rd ed. Editorial Pòrtic, Barcelona, Spain.

Camagni, R., M. Gibelli, and P. Riagamonti. 2002. Urban mobility and urban form: The social and environmental costs of different patterns of urban expansion. Ecol. Econ. 40:199-216.
Cameron, R.W.F., T. Blanusa, J.E. Taylor, A. Salisbury, A.J. Halstead, B. Henricot, and K. Thompson. 2012. The domestic garden - Its contribution to urban green infrastructure. Urban For. Urban Green. 11:129-137.

Cartographic Institute of Catalonia. 2013. Insitut Cartogràfic de Catalunya, Generalitat de Catalunya. 22 Jan. 2013. $<$ http://www.icc.es/>.

Chesnutt, T. and C. McSpadden. 1991. A model-based evaluation of Westchester water conservation program. A\&N Technical Services, San Diego, CA.

Contreras, F., A. González, J. López, and A. Calvo. 2006. Estimación de necesidades hídricas para especies de jardín en la región de Murcia: Adaptación de WUCOLS y utilización del sistema de información agraria de Murcia. III Jornadas Ibéricas de Horticultura Ornamental, Almería, Spain.

Costello, L. and K.S. Jones. 2014. WUCOLS IV. Water use classification of landscape species. 23 Dec. 2014. <http://ucanr.edu/sites/WUCOLS/>.

Costello, L.R., N.P. Matheny, and J.R. Clark. 2000. A guide to estimating irrigation water needs of landscape plantings in California. The landscape coefficient method and WUCOLS III. 12 Dec. 2012. <http://www.water.ca.gov/ wateruseefficiency/docs/wucols00.pdf>.

Directorate General for Cadastre Electronic Site. 2012. Spanish Government, Ministry of Finances and Public Administrations, Madrid, Spain. 6 Apr. 2012. <http://wwwl.sedecatastro.gob.es/ ovcInicio.aspx $>$.

Domene, E. and D. Saurí. 2003. Modelos urbanos y consumo de agua. El riego de jardines privados en la región metropolitana de Barcelona. Investigaciones Geográficas 32:5-17.

Domene, E. and D. Saurí. 2006. Urbanization and water consumption: Influencing factors in the metropolitan region of Barcelona. Urban Stud. 43:1605-1623.

Domene, E., D. Saurí, and M. Parés. 2005. Urbanization and sustainable resource use: The case of garden watering in the Metropolitan Region of Barcelona. Urban Geogr. 26:520-533.

Douglas, L. and J.H. Lawrence. 2011. Public spaces, private gardens: A history of designed landscapes in New Orleans. Louisiana State Univ. Press. Baton Rouge, LA.

Dunn, O.J. 1964. Multiple contrasts using rank sums. Technometrics 5:241-252.

Endter-Wada, J., J. Kurtzman, S. Keenan, R. Kjelgren, and C.M.U. Neale. 2008.
Situational waste in landscape watering: Residential and business water use in an urban Utah community. J. Amer. Water Resources Assn. 44:902-920.

European Environment Agency. 2009. Water resources across-Europe confronting water scarcity and drought. EEA Report 2/2009. 20 Aug. 2010. <http:// www.eea.europa.eu/publications/waterresources-across-europe $>$.

Fernández-Cañero, R., J. Ordovás, and M.A. Herrera Machuca. 2011. Domestic gardens as water-wise landscapes: A case of study in southwestern Europe. HortTechnology 21:616-623.

Fuentes, J.L. 2003. Técnicas de riego. Ediciones Mundi-Prensa, Madrid, Spain.

Garcia, X., A. Llausàs, and A. Ribas. 2013. Landscaping patterns and sociodemographic profiles in suburban areas: Implications for water conservation along the Mediterranean coast. Urban Water J. $11: 31-41$.

Gaston, K., P.H. Warren, K. Thompson, and R.M. Smith. 2005. Urban domestic gardens (IV): The extent of the resource and its associated features. Biodivers. Conserv. 14:3327-3349.

Generalitat de Catalunya. 2007. Generalitat de Catalunya, Legislative Decree 84/ 2007. Tercer d'abril, d'adopció de mesures excepcionals i d'emergència en relació amb la utilització dels recursos hídrics. 29 Jan. 2014. <http://aca-web. gencat.cat/aca/documents/ca/sequera/ decret_sequera_2007.pdf>.

Hope, D., C. Gries, W.X. Zhu, W.F. Fagan, C.L. Redman, N.B. Grimm, A.L. Nelson, C. Martin, and A. Kinzig. 2003. Socioeconomics drive urban plant diversity. Proc. Natl. Acad. Sci. U.S.A. 100: 8788-8792.

Hurd, B., R. St. Hilaire, and J. White. 2006. Residential landscapes, homeowner attitudes and water-wise choices in New Mexico. HortTechnology 16:241-246.

Jaganmohan, M., L.S. Vailshery, D. Gopal, and H. Nagendra. 2012. Plant diversity and distribution in urban domestic gardens and apartments in Bangalore, India. Urban Ecosyst. 15:911-925.

Larsen, L. and S.L. Harlan. 2006. Desert dreamscapes: Residential landscape preference and behaviour. Landsc. Urban Plan. 78:85-100.

Larson, K.L., D. Casagrande, S.L. Harlan, and S.T. Yabiku. 2009. Residents' yard choices and rationales in a desert city: Social priorities, ecological impacts, and decision tradeoffs. Environ. Mgt. 44:921-937.

Llebot, J.E. (ed.). 2010. Segon informe sobre el canvi climàtic a Catalunya. Generalitat 
de Catalunya Institut d'Estudis Catalans, Barcelona, Spain.

Lynch, F., M.R. Hollnsteiner, and L.C. Corvar. 1974. Data gathering by social survey. Trial edition. Social Science Council, Quezon City, Philippines.

Marco, A., T. Dutoit, M. DeschampsCottin, J.F. Mauffrey, M. Vennetier, and V. Bertaudiere-Montes. 2008. Gardens in urbanizing rural areas reveal an unexpected floral diversity related to housing density. C. R. Biol. 331:452-465.

Martín, A., R. Ávila, Ma.C. Yruela, R. Plaza, A. Navas, and R. Fernández. 2004. Manual de riego de jardines. Editorial de la Consejería de Agricultura y Pesca, Junta de Andalucía, Seville, Spain.

Martin, C.A. 2001. Landscape water use in Phoenix, Arizona. Desert Plants 17(2):26-31.

Martin, C.A., P.S. Warren, and P. Kinzig. 2003. Landscape vegetation in small urban parks and surrounding neighborhoods: Are socioeconomic characteristics a useful predictor of vegetation taxa richness and abundance? HortScience 38(5):733 (abstr.).

Mayer, P.W., W.B. DeOreo, E. Opitz, J. Kiefer, B. Dziegielewski, W. Davis, B. Dziegielewski, and J.O. Nelson. 1999. Residential end uses of water. Amer. Water Works Assn. Res. Foundation, Denver, CO.

Mustafa, D., T.A. Smucker, F. Ginn, R. Johns, and S. Connely. 2010. Xeriscape people and the cultural politics of turfgrass transformation. Environ. Plan. D Soc. Space 28:600-617.

Nielson, L. and C.L. Smith. 2005. Influences on residential yard care and water quality: Tualatin watershed, Oregon. J. Amer. Water Resources Assn. 41:93-106.

Nouri, H., S. Beecham, A.M. Hassanli, and F. Kazemi. 2013. Water requirements of urban landscape plants: A comparison of three factor-based approaches. Ecol. Eng. 57:276-284.

Osmond, D.L. and D.H. Hardy. 2004. Characterization of turf practices in five North Carolina communities. J. Environ. Qual. 33:565-575.
Parés-Franzi, M. 2005. Espai públic enjardinat: Impactes ambientals, model urbà i individualització a la Regió Metropolitana de Barcelona. Doc. Anal. Geogr. 45:91-110.

Raunkiaer, C. 1934. The life forms of plants and statistical plant geography: Being the collected papers of C. Raunkiaer. Clarendon Press, Oxford, UK.

Renwick, M. and S. Archibald. 1998. Demand side management policies for residential water use: Who bears the conservation burden? Land Econ. 74:343359.

Robbins, P., A. Polderman, and T. Birkenholtz. 2001. Lawns and toxins: An ecology of the city. Cities 18:369-380.

Salvador, R., C. Bautista-Capetillo, and E. Playán. 2011. Irrigation performance in private urban landscapes: A study case in Zaragoza (Spain). Landsc. Urban Plan. 100:302-311.

Saurí, D. 2003. Lights and shadows of urban water demand management: The case of the Metropolitan Region of Barcelona. Eur. Plan. Stud. 11:229-243.

Saurí, D., F. Breton, A. Ribas, J.C. Llurdés, and F. Romagosa. 2000. The ecological values of traditional land use in low-lying coastal environments: The example of the Aiguamolls de l'Empordà. Costa Brava. J. Environ. Plan. Mgt. 43:277-290.

Smith, R.M., K. Thompson, J.G. Hodgson, P.H. Warren, and K.J. Gaston. 2006. Urban domestic gardens (IX): Composition and richness of the vascular plant flora, and implications for native biodiversity. Biol. Conserv. 129:312-322.

Smith, R.M., K.J. Gaston, P.H. Warren, and K. Thompson. 2005. Urban domestic gardens (V): Relationships between landcover composition, housing and landscape. Landsc Ecol. 20:235-253.

St. Hilaire, R., D.M. VanLeeuwen, and P. Torres. 2010. Landscape preferences and water conservation choices of residents in a high desert environment. HortTechnology 20:308-314.

St. Hilaire, R., M.A. Arnold, D.C. Wilkerson, D.A. Devitt, B.H. Hurd, B.J.
Lesikar, V.I. Lohr, C.A. Martin, G.V. McDonald, R.L. Morris, D.R. Pittenger, D.A. Shaw, and D.F. Zoldoske. 2008. Efficient water use in residential urban landscapes. HortScience 43:2081-2092.

Statistical Institute of Catalonia. 2013. Institut d'Estadística de Catalunya, Generaliat de Catalunya, Barcelona, Spain. 12 Mar. 2013. $<$ http://www.idescat.cat/>.

Stocker, F.F., D. Qin, M.G.-K. Plattner, M. Tignor, S.K. Allen, J. Boschung, A. Nauels, Y. Xia, V. Bex, and P.M. Midgley (eds.). 2013. Climate change 2013: The physical science basis. Contribution of Working Group I to the Fifth Assessment Report of the Intergovernmental Panel on Climate Change. Cambridge Univ. Press, Cambridge, UK/New York, NY.

Syme, G.J., Q. Shao, M. Po, and E. Campbell. 2004. Predicting and understanding home garden water use. Landsc. Urban Plan. 68:121-128.

United Nations Environment Programme/Mediterranean Action PlanPlan Bleu. 2009. State of the environment and development in the Mediterranean. Athens: PNUE/PAM-Plan Bleu. 10 Aug. 2010. <http://www.planbleu.org/ publications/SoED2009_EN.pdf>.

United Nations-Water. 2012. Status report on the application of integrated approaches to water resources management. 7 Mar. 2011. <http://www.unwater.org/downloads/ UNW_status_report_Rio2012.pdf>.

Varlamoff, S., W.J. Florkowski, J.L. Jordan, J. Latimer, and K. Braman. 2001. Georgia homeowner survey of landscape management practices. HortTechnology 11:326-331.

Wade, G.L., J.T. Midcap, K.D. Coder, G. Landry, A.W. Tyson, and N. Weatherly. 2007. Xeriscape, a guide to developing a water-wise landscape. 2 Nov. 2012. <http://www.marex.uga.edu/advisory/ Library/CSCPpdfs/Xeriscape.pdf>.

Yabiku, S.T., D.G. Casagrande, and E. Farley-Metzger. 2008. Preferences for landscape choice in a Southwestern desert city. Environ. Behav. 40:382-400. 